\title{
Pedobacter insulae sp. nov., isolated from soil
}

Correspondence Jung-Hoon Yoon jhyoon@kribb.re.kr

\section{Jung-Hoon Yoon, So-Jung Kang, Hyun Woo Oh and Tae-Kwang Oh}

Korea Research Institute of Bioscience and Biotechnology (KRIBB), PO Box 115, Yusong, Taejon, Korea

\begin{abstract}
A Gram-negative, non-motile, rod-shaped bacterium, DS $-139^{\top}$, was isolated from a soil sample collected from Dokdo, Korea, and subjected to a polyphasic taxonomic analysis. Strain DS-139 ${ }^{\top}$ grew optimally at $25{ }^{\circ} \mathrm{C}$ and $\mathrm{pH} 6.5-7.5$ in the presence of $0-0.5 \%(\mathrm{w} / \mathrm{v}) \mathrm{NaCl}$. It contained MK-7 as the predominant menaquinone and iso- $\mathrm{C}_{15: 0}, \mathrm{C}_{16: 1} \omega 7 \mathrm{c}$ and/or iso- $\mathrm{C}_{15: 0} 2-\mathrm{OH}$ and iso- $\mathrm{C}_{17: 0} 3-\mathrm{OH}$ as the major fatty acids. The DNA G $+\mathrm{C}$ content was $39.4 \mathrm{~mol} \%$. Phylogenetic analyses based on $16 \mathrm{~S}$ rRNA gene sequences revealed that strain DS-39 ${ }^{\top}$ belongs to the genus Pedobacter in the family Sphingobacteriaceae. The similarity values between the $16 \mathrm{~S}$ rRNA gene sequence of strain DS $139^{\top}$ and those of the type strains of recognized Pedobacter species, except Pedobacter saltans, were in the range 93.9-96.7\%. The differential phenotypic properties, together with the phylogenetic distinctiveness, were sufficient to assign strain DS $-139^{\top}$ to a species that is separate from recognized Pedobacter species. On the basis of the phenotypic and phylogenetic data, therefore, strain DS $-139^{\top}$ represents a novel species of the genus Pedobacter, for which the name Pedobacter insulae sp. nov. is proposed. The type strain is DS $139^{\top}\left(=\right.$ KCTC $12820^{\top}=$ DSM $\left.18684^{\top}\right)$.
\end{abstract}

The genus Pedobacter was proposed by Steyn et al. (1998) with the reclassification of two Sphingobacterium species and the description of two novel species. At the time of writing, the genus comprises 13 species with validly published names: Pedobacter heparinus, P. piscium, $P$. africanus and $P$. saltans (Steyn et al., 1998), P. cryoconitis (Margesin et al., 2003), P. himalayensis (Shivaji et al., 2005), P. caeni (Vanparys et al., 2005), P. sandarakinus (Yoon et al., 2006), P. roseus (Hwang et al., 2006), P. aquatilis (Gallego et al., 2006), P. ginsengisoli (Ten et al., 2006), P. panaciterrae (Yoon et al., 2007) and P. suwonensis (Kwon et al., 2007). In this study, we report on the taxonomic characterization of a bacterial strain, DS- $139^{\mathrm{T}}$, that is phylogenetically closely related to the genus Pedobacter.

A soil sample collected from Dokdo $\left(37^{\circ} 14^{\prime} 12^{\prime \prime} \mathrm{N} 131^{\circ} 52^{\prime}\right.$ $07^{\prime \prime} \mathrm{E}$ ), an island in Korea, was used as the source for the isolation of bacterial strains. Strain DS- $139^{\mathrm{T}}$ was isolated by means of the standard dilution plating technique, at $25{ }^{\circ} \mathrm{C}$ on 10-fold-diluted nutrient agar (Difco). The morphological, physiological and biochemical characteristics of strain DS- $139^{\mathrm{T}}$ were investigated using routine cultivation on trypticase soy agar (TSA; Difco) at $25{ }^{\circ} \mathrm{C}$. The cell morphology was examined using light microscopy (E600; Nikon) and transmission electron microscopy. Flagellation was determined by using a Philips CM-20 transmission electron microscope to investigate cells from exponentially

The GenBank/EMBL/DDBJ accession number for the 16S rRNA gene sequence of strain DS-139 ${ }^{\top}$ is EF100697. growing cultures. The cells were negatively stained with $1 \%(\mathrm{w} / \mathrm{v})$ phosphotungstic acid and the grids were examined after being air-dried. Gliding motility was determined as described by Bowman (2000) using quarter-strength trypticase soy broth (TSB; Difco) solidified with $1 \%(\mathrm{w} / \mathrm{v})$ agarose and R2A agar (Difco). The Gram reaction was determined by using the bioMérieux Gram stain kit according to the manufacturer's instructions. Growth at various temperatures $\left(4-40{ }^{\circ} \mathrm{C}\right)$ was measured on TSA. Growth in the absence of $\mathrm{NaCl}$ and at various $\mathrm{NaCl}$ concentrations $(0.5 \%$, w/v, and $1.0-5.0 \%$, $\mathrm{w} / \mathrm{v}$, in $1.0 \%$ increments) was investigated in trypticase soy broth prepared according to the formula of the Difco medium except that no $\mathrm{NaCl}$ was used. The $\mathrm{pH}$ range for growth was determined in nutrient broth (Difco) adjusted to various $\mathrm{pH}$ values $(\mathrm{pH} 4.5-10.5$ in increments of $0.5 \mathrm{pH}$ units) prior to sterilization by the addition of $\mathrm{HCl}$ or $\mathrm{Na}_{2} \mathrm{CO}_{3}$. Growth under anaerobic conditions was determined after incubation in an anaerobic chamber on TSA and on TSA supplemented with nitrate, both of which had been prepared anaerobically using nitrogen. Catalase and oxidase activities and the hydrolysis of casein, gelatin, hypoxanthine, starch, Tweens 20, 40, 60 and 80, tyrosine, urea and xanthine were determined as described by Cowan \& Steel (1965). DNase activity was examined by using DNase test agar with methyl green (Difco). Aesculin hydrolysis and nitrate reduction were studied as described previously (Lanyi, 1987). The presence of flexirubin-type pigments was investigated as described by Reichenbach (1992). Antibiotic susceptibility was tested on TSA plates, 
Table 1. Differential phenotypic characteristics of strain $D S-139^{\top}$ and some phylogenetically related Pedobacter species

Species: 1, P. insulae sp. nov. (strain DS-139 ${ }^{\mathrm{T}}$ ); 2, P. heparinus; 3, P. africanus; 4, P. piscium; 5, P. cryoconitis; 6, P. himalayensis; 7, P. caeni; 8, P. ginsengisoli; 9, P. panaciterrae. Data are from Steyn et al. (1998), Margesin et al. (2003), Shivaji et al. (2005), Vanparys et al. (2005), Ten et al. (2006), Yoon et al. (2006) and this study. All species are positive for catalase, oxidase, acid phosphatase ${ }^{a b c d_{\ddagger}}$, alkaline phosphatase ${ }^{a b c d}$ and leucine arylamidase $^{a b c d}$ and for assimilation of D-glucose, D-mannose, D-cellobiose, $\mathrm{N}$-acetylglucosamine, amygdalin ${ }^{c}$, lactose, melibiose, sucrose and trehalose. All species stain Gram-negative and are negative for sporulation, urease, production of indole and $\mathrm{H}_{2} \mathrm{~S}$, nitrate reduction, assimilation of

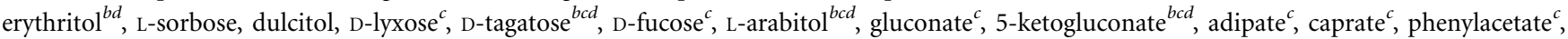
citrate and malate and for susceptibility to ampicillin ${ }^{b d}$ (no data for P. piscium) and kanamycin ${ }^{\text {bd }}$ (no data for P. africanus or P. piscium). + , Positive; -, negative; w, weakly positive; $\mathrm{v}$, variable (data in parentheses are for the type strain); ND, no data available.

\begin{tabular}{|c|c|c|c|c|c|c|c|c|c|}
\hline Characteristic & 1 & 2 & 3 & 4 & 5 & 6 & 7 & 8 & 9 \\
\hline Cell shape & Rod & Short rod & ND & Long rod & Long rod & Long rod & Rod & Rod & $\operatorname{Rod}$ \\
\hline Colony colour ${ }^{\star}$ & LY & TY & TY & Y/CWH & CWH & WH & $\mathrm{CWH}-\mathrm{Y}$ & WH & wH \\
\hline Growth on MacConkey agar & - & - & - & - & - & + & ND & - & - \\
\hline Gliding motility & - & + & - & - & + & - & - & - & - \\
\hline Arginine dihydrolase & - & - & - & - & - & + & - & - & - \\
\hline Tryptophan deaminase & - & - & - & - & - & + & $\mathrm{ND}$ & - & - \\
\hline Hydrolysis of aesculin & + & + & + & + & + & + & + & - & - \\
\hline \multicolumn{10}{|l|}{ Enzyme activity (API ZYM) } \\
\hline Esterase (C4) & - & $+\dagger$ & - & $+\dagger$ & $\mathrm{w}^{a_{\ddagger}}$ & $\mathrm{w}^{b}$ & - & $+{ }^{c}$ & $-{ }^{d}$ \\
\hline Esterase lipase (C8) & - & + & + & + & $+^{a}$ & $+{ }^{b}$ & + & $+{ }^{c}$ & $+{ }^{d}$ \\
\hline Lipase (C14) & - & $-\dagger$ & - & $\mathrm{v} \dagger$ & $-{ }^{a}$ & $-{ }^{b}$ & - & $-^{c}$ & $-{ }^{d}$ \\
\hline$\alpha$-Galactosidase & - & $+\dagger$ & - & $+\dagger$ & $-{ }^{a}$ & $-{ }^{b}$ & - & $+{ }^{c}$ & $+{ }^{d}$ \\
\hline$\beta$-Galactosidase & - & + & + & + & $-{ }^{a}$ & $-{ }^{b}$ & + & - & + \\
\hline$\beta$-Glucuronidase & - & $-\dagger$ & - & $\mathrm{v} \dagger$ & $-{ }^{a}$ & $-{ }^{b}$ & - & $-^{c}$ & $-{ }^{d}$ \\
\hline$\alpha$-Glucosidase & + & + & + & + & $+{ }^{a}$ & $\mathrm{w}^{b}$ & - & $+{ }^{c}$ & $+{ }^{d}$ \\
\hline$\beta$-Glucosidase & - & $+\dagger$ & $\mathrm{V}(-)$ & $+\dagger$ & + & + & - & $-^{c}$ & $-{ }^{d}$ \\
\hline$N$-Acetyl- $\beta$-glucosaminidase & + & + & + & + & $+{ }^{a}$ & $+{ }^{b}$ & - & $+{ }^{c}$ & $+{ }^{d}$ \\
\hline$\alpha$-Mannosidase & - & $+\dagger$ & $\mathrm{v}(\mathrm{w})$ & $+\dagger$ & $-{ }^{a}$ & $-{ }^{b}$ & - & $-^{c}$ & $-{ }^{d}$ \\
\hline$\alpha$-Fucosidase & - & $-\dagger$ & - & $-\dagger$ & $-{ }^{a}$ & $\mathrm{w}^{b}$ & - & $-^{c}$ & $\mathrm{w}^{d}$ \\
\hline \multicolumn{10}{|l|}{ Assimilation of: } \\
\hline Glycerol & + & - & - & - & - & + & - & + & + \\
\hline D-Arabinose & - & - & $\mathrm{V}(-)$ & - & - & + & - & - & + \\
\hline D-Fructose & - & + & $\mathrm{V}(-)$ & + & + & + & - & + & - \\
\hline \multicolumn{10}{|l|}{ Assimilation of: } \\
\hline L-Rhamnose & $\mathrm{W}$ & + & + & $\mathrm{V}$ & - & + & - & - & - \\
\hline Inositol & - & - & - & - & - & - & - & - & + \\
\hline Mannitol & - & + & - & - & - & + & - & - & - \\
\hline D-Sorbitol & - & + & - & - & - & + & - & - & - \\
\hline Methyl $\alpha$-D-mannoside & $\mathrm{w}$ & + & + & - & - & + & + & $+^{c}$ & $+{ }^{d}$ \\
\hline Methyl $\alpha$-D-glucoside & + & + & + & + & $\mathrm{w}$ & + & + & $+{ }^{c}$ & $+{ }^{d}$ \\
\hline Arbutin & + & $\mathrm{V}(-)$ & $\mathrm{V}(-)$ & + & + & + & + & $-^{c}$ & $+{ }^{d}$ \\
\hline Salicin & + & + & $\mathrm{v}(+)$ & + & + & + & + & + & + \\
\hline Maltose & + & + & $\mathrm{v}(+)$ & + & + & + & + & + & + \\
\hline Inulin & - & - & - & - & $\mathrm{w}$ & + & - & + & + \\
\hline
\end{tabular}


Table 1. cont.

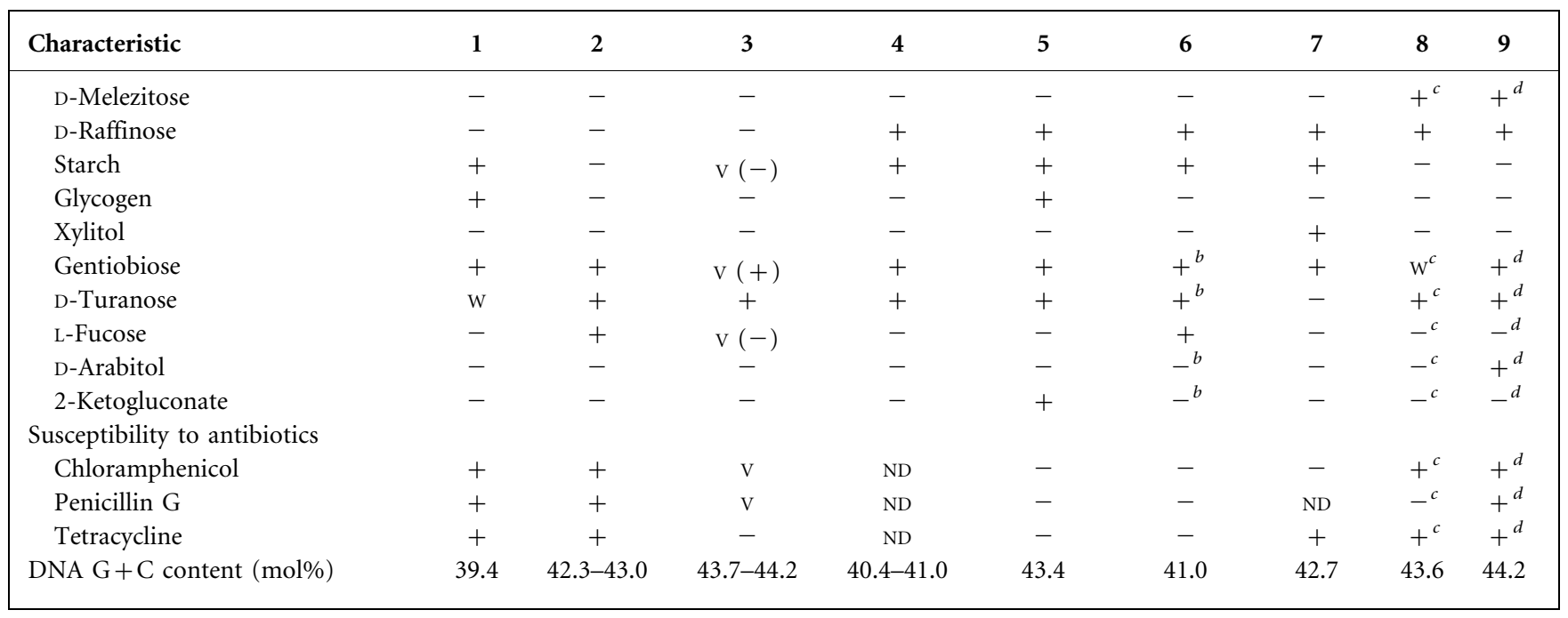

${ }^{*} \mathrm{CWH}$, Creamy white; LY, light yellow; TY, translucent yellow; WH, white; Y, yellow.

$\dagger$ Data from Takeuchi \& Yokota (1992).

$\ddagger$ Data obtained in this study for the type strains of the following species: $a$, P. cryoconitis; $b$, P. ginsengisoli; $c$, P. himalayensis; $d$, P. panaciterrae.

using antibiotic discs containing the following: polymyxin B, $100 \mathrm{U}$; streptomycin, $50 \mu \mathrm{g}$; penicillin $\mathrm{G}, 20 \mathrm{U}$; chloramphenicol, $100 \mu \mathrm{g}$; ampicillin, $10 \mu \mathrm{g}$; cephalothin, $30 \mu \mathrm{g}$; gentamicin, $30 \mu \mathrm{g}$; novobiocin, $5 \mu \mathrm{g}$; tetracycline, $30 \mu \mathrm{g}$; kanamycin, $30 \mu \mathrm{g}$; lincomycin, $15 \mu \mathrm{g}$; oleandomycin, $15 \mu \mathrm{g}$; neomycin, $30 \mu \mathrm{g}$; and carbenicillin, $100 \mu \mathrm{g}$. Assimilation of various substrates, enzyme activities and other physiological and biochemical properties were tested by using the API 20E, API 20NE, API $50 \mathrm{CH}$ and API ZYM systems (bioMérieux); the cells were suspended in AUX medium according to the manufacturer's instructions to inoculate the API $50 \mathrm{CH}$ system.

The type strains of four Pedobacter species were used as reference strains for phenotypic characterization: $P$. cryoconitis KACC $11394^{\mathrm{T}}$ and P. himalayensis KACC $11499^{\mathrm{T}}$ were obtained from the Korean Agricultural Culture Collection (KACC), Suwon, Korea, and P. ginsengisoli KCTC $12576^{\mathrm{T}}$ and $P$. panaciterrae KCTC $12594^{\mathrm{T}}$ were obtained from the Korean Collection for Type Cultures (KCTC), Taejon, Korea.

Cell biomass for DNA extraction and for isoprenoid quinone analysis was obtained from cultivation in TSB at $25{ }^{\circ} \mathrm{C}$. Chromosomal DNA was isolated and purified according to the method described by Yoon et al. (1996), except that RNase T1 was used in combination with RNase A to minimize contamination with RNA. The $16 \mathrm{~S}$ rRNA gene was amplified by using a PCR with two universal primers, as described previously (Yoon et al., 1998). Sequencing of the amplified 16S rRNA gene and phylogenetic analysis were performed as described by Yoon et al. (2003). Isoprenoid quinones were extracted according to the method of Komagata \& Suzuki (1987) and analysed using reversed-phase HPLC and a YMC ODS-A
$(250 \times 4.6 \mathrm{~mm})$ column. For fatty acid methyl ester analysis, biomass of strain DS- $139^{\mathrm{T}}$ was harvested from TSA plates after incubation for 7 days at $25^{\circ} \mathrm{C}$. The fatty acid methyl esters were extracted and prepared according to the standard protocol of the MIDI/Hewlett Packard Microbial Identification System (Sasser, 1990). The DNA $\mathrm{G}+\mathrm{C}$ content was determined by using the method of Tamaoka \& Komagata (1984) with the modification that DNA was hydrolysed and the resultant nucleotides were analysed by reversed-phase HPLC.

Morphological, cultural, physiological and biochemical characteristics of strain DS- $139^{\mathrm{T}}$ are given in the species description and in Table 1. The almost-complete 16S rRNA gene sequence of strain DS- $139^{\mathrm{T}}$, determined in this study, comprised $1475 \mathrm{nt}$ (approx. $96 \%$ of the Escherichia coli $16 \mathrm{~S}$ rRNA gene sequence). 16S rRNA gene sequence analyses showed that strain DS- $139^{\mathrm{T}}$ was most closely related phylogenetically to the genus Pedobacter within the family Sphingobacteriaceae (Fig. 1). In the neighbour-joining tree based on 16S rRNA gene sequences, strain DS- $139^{\mathrm{T}}$ formed a distinct phylogenetic lineage within the cluster comprising Pedobacter species (Fig. 1). Strain DS- $139^{\mathrm{T}}$ exhibited $16 \mathrm{~S}$ rRNA gene sequence similarity values ranging from 93.9\% (P. aquatilis AR $107^{\mathrm{T}}$ ) to $96.7 \%$ (P. caeni $\mathrm{LMG}$ $\left.22862^{\mathrm{T}}\right)$ with respect to the type strains of Pedobacter species (except P. saltans DSM $12145^{\mathrm{T}}$ ) and showed less than $90.4 \%$ sequence similarity with respect to other species.

Strain DS- $139^{\mathrm{T}}$ contained MK-7 (at a peak area ratio of approximately $96 \%$ ) as the predominant isoprenoid quinone. The fatty acid profile comprised the following (of those making up $>1.0 \%$ of total fatty acids): branched fatty acids iso- $\mathrm{C}_{15: 0} \quad(26.0 \%)$, iso- $\mathrm{C}_{17: 1} \omega 9 \mathrm{c} \quad(6.9 \%)$, anteiso- $\mathrm{C}_{17: 1} \omega 9 c(4.7 \%)$, anteiso- $\mathrm{C}_{15: 0}(3.2 \%)$, iso- $\mathrm{C}_{16: 1}$ 


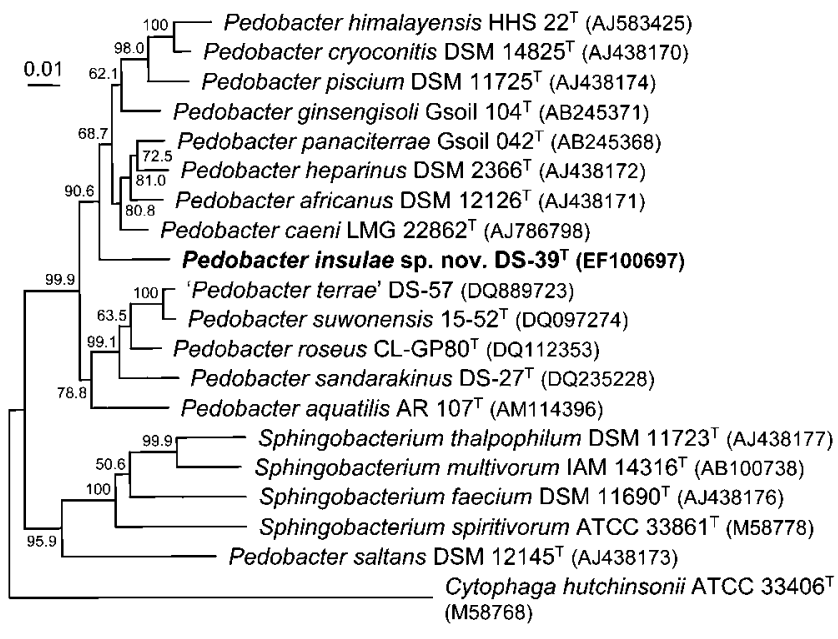

Fig. 1. Neighbour-joining phylogenetic tree, based on $16 \mathrm{~S}$ rRNA gene sequences, showing the positions of strain DS $139^{\top}$ and some related taxa. Bootstrap percentages (from 1000 replications) are shown at nodes only if they are $\geqslant 50 \%$. Cytophaga hutchinsonii ATCC $33406^{\top}$ was used as the outgroup. Bar, 0.01 substitutions per nucleotide position.

$(2.1 \%)$ and iso- $\mathrm{C}_{16: 0}(2.0 \%)$; summed feature 3 , comprising $\mathrm{C}_{16: 1} \omega 7 c$ and/or iso- $\mathrm{C}_{15: 0} 2-\mathrm{OH}(19.1 \%)$; hydroxy fatty acids iso- $\mathrm{C}_{17: 0} 3-\mathrm{OH}(11.6 \%), \mathrm{C}_{17: 0} 2-\mathrm{OH}(8.9 \%)$, iso- $\mathrm{C}_{16: 0} 3-\mathrm{OH}(3.1 \%)$, iso- $\mathrm{C}_{15: 0} 3-\mathrm{OH}(2.1 \%)$ and $\mathrm{C}_{15: 0}$ $2-\mathrm{OH}(1.5 \%)$; and unsaturated fatty acids $\mathrm{C}_{15: 1} \omega 6 c$ $(1.1 \%)$ and $\mathrm{C}_{16: 1} \omega 5 c(1.0 \%)$. This fatty acid profile was similar to those of recognized Pedobacter species, although there were differences in the proportions of some fatty acids, perhaps because of differences in the analytical conditions used (e.g. cultivation, extraction and apparatus; Shivaji et al., 2005; Vanparys et al., 2005; Yoon et al., 2006; Hwang et al., 2006; Ten et al., 2006). The DNA G+C content of strain DS- $139^{\mathrm{T}}$ was $39.4 \mathrm{~mol} \%$. These chemotaxonomic properties are in agreement with the result of a monothetic phylogenetic classification that placed strain DS-139 ${ }^{\mathrm{T}}$ within the genus Pedobacter (Steyn et al., 1998; Margesin et al., 2003; Shivaji et al., 2005; Vanparys et al., 2005; Yoon et al., 2006; Hwang et al., 2006; Ten et al., 2006). Strain DS- $139^{\mathrm{T}}$ differs from some phylogenetically related Pedobacter species in several phenotypic characteristics, as shown in Table 1. The phylogenetic distinctiveness of DS- $139^{\mathrm{T}}$, together with the differential phenotypic properties, is sufficient to show that the strain is distinct from recognized Pedobacter species (Stackebrandt \& Goebel, 1994). Therefore, on the basis of the data presented, strain DS- $139^{\mathrm{T}}$ represents a novel species of the genus Pedobacter, for which the name Pedobacter insulae sp. nov. is proposed.

\section{Description of Pedobacter insulae sp. nov.}

Pedobacter insulae (in.su'lae. L. fem. gen. n. insulae of an island, referring to the source of isolation of the type strain).
Cells are Gram-negative, non-spore-forming, non-flagellated rods $(0.3-0.5 \times 0.7-6.0 \mu \mathrm{m})$; occasionally cells greater than $10.0 \mu \mathrm{m}$ in length occur. Colonies on TSA are circular, convex, smooth, glistening, light yellow in colour and 1.0-2.0 $\mathrm{mm}$ in diameter after incubation for 7 days at $25{ }^{\circ} \mathrm{C}$. Optimal growth occurs at $25{ }^{\circ} \mathrm{C}$; growth occurs at 4 and $31{ }^{\circ} \mathrm{C}$, but not at $32{ }^{\circ} \mathrm{C}$. The optimal $\mathrm{pH}$ for growth is 6.5-7.5; growth occurs at $\mathrm{pH} 6.0$ and 10.0, but not at $\mathrm{pH} 5.5$ or 10.5. Optimal growth occurs in the presence of $0-0.5 \%(\mathrm{w} / \mathrm{v}) \mathrm{NaCl}$; growth does not occur in the presence of more than $2 \%(\mathrm{w} / \mathrm{v}) \mathrm{NaCl}$. Growth does not occur under anaerobic conditions on TSA or on TSA supplemented with nitrate. DNase-positive. Starch, tyrosine and Tweens 20, 40, 60 and 80 are hydrolysed, but casein, gelatin, hypoxanthine and xanthine are not. Ornithine decarboxylase is absent. Naphthol-AS-BI-phosphohydrolase is present. Flexirubin-type pigments are absent. Susceptible to carbenicillin, cephalothin, gentamicin, lincomycin, novobiocin, oleandomycin and streptomycin, but not to neomycin or polymyxin $\mathrm{B}$. The predominant menaquinone is $\mathrm{MK}-7$. The major fatty acids $(>10 \%$ of total fatty acids) are iso- $\mathrm{C}_{15: 0}, \mathrm{C}_{16: 1} \omega 7 c$ and/or iso- $\mathrm{C}_{15: 0}$ 2- $\mathrm{OH}$ and iso- $\mathrm{C}_{17: 0} 3-\mathrm{OH}$. The DNA $\mathrm{G}+\mathrm{C}$ content is $39.4 \mathrm{~mol} \%$ (HPLC). Other phenotypic properties are shown in Table 1.

The type strain, DS- $139^{\mathrm{T}} \quad\left(=\right.$ KCTC $12820^{\mathrm{T}}=\mathrm{DSM}$ $18684^{\mathrm{T}}$ ), was isolated from a soil at Dokdo, an island in Korea.

\section{Acknowledgements}

This work was supported by the 21C Frontier Program of Microbial Genomics and Applications (grant MG05-0401-2-0) and the Support and Application Project of Biological Resources (grant M10508050004-06N0805-00410) from the Ministry of Science and Technology (MOST) of the Republic of Korea.

\section{References}

Bowman, J. P. (2000). Description of Cellulophaga algicola sp. nov., isolated from the surfaces of Antarctic algae, and reclassification of Cytophaga uliginosa (ZoBell and Upham 1944) Reichenbach 1989 as Cellulophaga uliginosa comb. nov. Int J Syst Evol Microbiol 50, 1861-1868.

Cowan, S. T. \& Steel, K. J. (1965). Manual for the Identification of Medical Bacteria. London: Cambridge University Press.

Gallego, V., Garcia, M. T. \& Ventosa, A. (2006). Pedobacter aquatilis sp. nov., isolated from drinking water, and emended description of the genus Pedobacter. Int J Syst Evol Microbiol 56, 1853-1858.

Hwang, C. Y., Choi, D. H. \& Cho, B. C. (2006). Pedobacter roseus sp. nov., isolated from a hypertrophic pond, and emended description of the genus Pedobacter. Int J Syst Evol Microbiol 56, 1831-1836.

Komagata, K. \& Suzuki, K. (1987). Lipid and cell wall analysis in bacterial systematics. Methods Microbiol 19, 161-207.

Kwon, S.-W., Kim, B. Y., Lee, K.-H., Jang, K.-Y., Seok, S.-J., Kwon, J.-S., Kim, W.-G. \& Weon, H. Y. (2007). Pedobacter suwonensis sp. nov., isolated from the rhizosphere of Chinese cabbage (Brassica campestris). Int J Syst Evol Microbiol 57, 480-484. 
Lanyi, B. (1987). Classical and rapid identification methods for medically important bacteria. Methods Microbiol 19, 1-67.

Margesin, R., Spröer, C., Schumann, P. \& Schinner, F. (2003). Pedobacter cryoconitis sp. nov., a facultative psychrophile from alpine glacier cryoconite. Int J Syst Evol Microbiol 53, 1291-1296.

Reichenbach, H. (1992). The order Cytophagales. In The Prokaryotes. A Handbook on the Biology of Bacteria: Ecophysiology, Isolation, Identification, Applications, 2nd edn, pp. 3631-3675. Edited by A. Balows, H. G. Trüper, M. Dworkin, W. Harder \& K. H. Schleifer. New York: Springer.

Sasser, M. (1990). Identification of bacteria by gas chromatography of cellular fatty acids, MIDI Technical Note 101. Newark, DE: MIDI Inc.

Shivaji, S., Chaturvedi, P., Reddy, G. S. N. \& Suresh, K. (2005). Pedobacter himalayensis sp. nov., from the Hamta glacier located in the Himalayan mountain ranges of India. Int J Syst Evol Microbiol 55, 1083-1088.

Stackebrandt, E. \& Goebel, B. M. (1994). Taxonomic note: a place for DNA-DNA reassociation and 16S rRNA sequence analysis in the present species definition in bacteriology. Int J Syst Bacteriol 44, 846-849.

Steyn, P. L., Segers, P., Vancanneyt, M., Sandra, P., Kersters, K. \& Joubert, J. J. (1998). Classification of heparinolytic bacteria into a new genus, Pedobacter, comprising four species: Pedobacter heparinus comb. nov., Pedobacter piscium comb. nov., Pedobacter africanus sp. nov. and Pedobacter saltans sp. nov. Proposal of the family Sphingobacteriaceae fam. nov. Int J Syst Bacteriol 48, 165-177.

Takeuchi, M. \& Yokota, A. (1992). Proposals of Sphingobacterium faecium sp. nov., Sphingobacterium piscium sp. nov., Sphingobacterium heparinum comb. nov., Sphingobacterium thalpophilum comb. nov., and two genospecies of the genus Sphingobacterium and synonymy of Flavobacterium yabuuchiae and Sphingobacterium spiritivorum. J Gen Appl Microbiol 38, 465-482.

Tamaoka, J. \& Komagata, K. (1984). Determination of DNA base composition by reversed-phase high-performance liquid chromatography. FEMS Microbiol Lett 25, 125-128.

Ten, L. N., Liu, Q.-M., Im, W.-T., Lee, M., Yang, D.-C. \& Lee, S.-T. (2006). Pedobacter ginsengisoli sp. nov., a novel DNase-producing bacterium isolated from soil of a ginseng field in South Korea. Int $J$ Syst Evol Microbiol 56, 2565-2570.

Vanparys, B., Heylen, K., Lebbe, L. \& De Vos, P. (2005). Pedobacter caeni sp. nov., a novel species isolated from a nitrifying inoculum. Int J Syst Evol Microbiol 55, 1315-1318.

Yoon, J.-H., Kim, H., Kim, S.-B., Kim, H.-J., Kim, W. Y., Lee, S. T., Goodfellow, M. \& Park, Y.-H. (1996). Identification of Saccharomonospora strains by the use of genomic DNA fragments and rRNA gene probes. Int J Syst Bacteriol 46, 502-505.

Yoon, J.-H., Lee, S. T. \& Park, Y.-H. (1998). Inter- and intraspecific phylogenetic analysis of the genus Nocardioides and related taxa based on 16S rRNA gene sequences. Int J Syst Bacteriol 48, 187-194.

Yoon, J.-H., Kim, I.-G., Shin, D.-Y., Kang, K. H. \& Park, Y.-H. (2003). Microbulbifer salipaludis sp. nov., a moderate halophile isolated from a Korean salt marsh. Int J Syst Evol Microbiol 53, 53-57.

Yoon, J.-H., Lee, M.-H., Kang, S.-J., Park, S.-Y. \& Oh, T.-K. (2006). Pedobacter sandarakinus sp. nov., isolated from soil. Int J Syst Evol Microbiol 56, 1273-1277.

Yoon, M.-H., Ten, L. N., Im, W.-T. \& Lee, S.-T. (2007). Pedobacter panaciterrae sp. nov., isolated from soil in South Korea. Int J Syst Evol Microbiol 57, 381-386. 